\title{
References, further reading and websites
}

\section{Chapter 1: Population}

References and further reading

Ageing and Mortality Statistics in the UK, National Statistician's Annual Article on the Population, available at:

http://www.statistics.gov.uk/cci/article.asp?!D=2079

Annual Report of the Registrar General for Northern Ireland, Northern Ireland Statistics and Research Agency, available at:

http://www.nisra.gov.uk/demography/default.asp22.htm

Annual Report of the Registrar General for Scotland, General Register Office for Scotland, available at:

http://www.gro-scotland.gov.uk/statistics/annrep/index.html

Asylum Statistics United Kingdom, 2007, Home Office, available at: http://www.homeoffice.gov.uk/rds/pdfs08/hosb1108.pdf

Birth Statistics, England and Wales (Series FM1), ONS, Internet only publication, available at:

www.statistics.gov.uk/statbase/Product.asp?vlnk=5768

Bradford B (2006), Who are the 'Mixed' ethnic group? Internet only publication, ONS, available at:

www.statistics.gov.uk/CCl/article.asp?ID $=1580$

Census 2001: First results on population for England and Wales, (ONS), TSO, available at:

www.statistics.gov.uk/census2001/downloads/pop2001ew.pdf

Control of Immigration: Statistics, United Kingdom, 2006, TSO, available at: http://www.homeoffice.gov.uk/rds/pdfs08/hosb1008.pdf

Europe in Figures - Population, Eurostat, available at:

http://epp.eurostat.ec.europa.eu/cache/ITY_OFFPUB/KS-

CD-06-001-01/EN/KS-CD-06-001-01-EN.PDF

Health Statistics Quarterly, ONS, Palgrave Macmillan, available at: http://www.statistics.gov.uk/statbase/Product.asp?vlnk=6725

International Migration Statistics (Series MN), ONS, Internet only publication, available at:

www.statistics.gov.uk/statbase/Product.asp?vlnk=507

Key Population and Vital Statistics (Series VS/PP1), ONS/TSO, available at: http://www.statistics.gov.uk/statbase/Product.asp?vlnk=539

Kramer S, The Fragile Male, British Medical Journal, available at: http://www.bmj.com/cgi/content/full/321/7276/1609

Mid-year Population Estimates, Northern Ireland, Northern Ireland Statistics and Research Agency, available at:

http://www.nisra.gov.uk/demography/default.asp17.htm

Mid-2007 Population Estimates Scotland, General Register Office for Scotland, Internet only publication, available at: http://www.gro-scotland.gov.uk/statistics/publications-and-data/ population-estimates/mid-2007-population-estimates-scotland/ index.html

Mid-year Population Estimates, United Kingdom, ONS, available at: http://www.statistics.gov.uk/statbase/Product.asp?vInk=15106

Mortality Statistics for England and Wales (Series DH2), ONS, Internet only publications, available at:

http://www.statistics.gov.uk/statbase/Product.asp?vlnk=618

National Population Projections, UK (Series PP2), ONS, available at: http://www.statistics.gov.uk/StatBase/Product. asp?vlnk=8519

Persons Granted British Citizenship, United Kingdom, 2007, Home Office, available at:

www.homeoffice.gov.uk/rds/pdfs08/hosb0508.pdf

Population in Europe 2007: first results, Eurostat, available at: http://epp.eurostat.ec.europa.eu/cache/ITY_OFFPUB/KS-SF-08-081/ EN/KS-SF-08-081-EN.PDF
Population Projections, Northern Ireland, Northern Ireland Statistics and Research Agency, available at: http://www.nisra.gov.uk/demography/default.asp20.htm

Population Projections, Scotland, General Register Office for Scotland, available at:

http://www.gro-scotland.gov.uk/statistics/publications-and-data/ popproj/projected-population-of-scotland-(2006-based)/index.html

Population Projections for Wales (sub-national), Welsh Assembly Government / Welsh Office Statistical Directorate, available at: http://new.wales.gov.uk/docrepos/40382/40382313/statistics/ population/pop-2007/sb49-2007?lang=en

Population Trends, ONS, Palgrave Macmillan, available at: http://www.statistics.gov.uk/STATBASE/Product.asp?vlnk=6303

World Population Prospects: The 2006 Revision, United Nations, available at:

http://www.un.org/esa/population/publications/wpp2006/wpp2006. htm

Other useful websites

National Statistics

www.statistics.gov.uk

Eurostat

www.europa.eu.int/comm/eurostat

General Register Office for Scotland www.gro-scotland.gov.uk

Government Actuary's Department www.gad.gov.uk

Home Office Immigration and Asylum Statistics www.homeoffice.gov.uk/rds/immigration-assylum-stats.html

Northern Ireland Statistics and Research Agency www.nisra.gov.uk

Scottish Government www.scotland.gov.uk

United Nations Population Division www.un.org/esa/population/unpop.htm

Welsh Assembly Government www.wales.gov.uk

\section{Chapter 2: Households and families}

References and further reading

Abortion Statistics, England and Wales: 2007, Department of Health, available at:

http://www.dh.gov.uk/en/Publicationsandstatistics/Publications/ PublicationsStatistics/DH_085508

Abortion Statistics, 2007, ISD Scotland, available at: http://www.isdscotland.org/isd/1918.html

Adoption Statistics (Series FM2), Office for National Statistics, available at: http://www.statistics.gov.uk/statbase/Product.asp?vlnk=581

Annual Report of the Registrar General for Northern Ireland, Northern Ireland Statistics and Research Agency, available at: http://www.nisra.gov.uk/demography/default.asp22.htm

Annual Report of the Registrar General for Scotland, General Register Office for Scotland, available at:

http://www.gro-scotland.gov.uk/statistics/index.html

Barlow A, Burgoyne C, Clery E and Smithson J, Cohabitation and the law: myths, money and the media, in British Social Attitudes: the 24th Report 
Birth Statistics, England and Wales (Series FM1), Office for National Statistics, available at:

http://www.statistics.gov.uk/statbase/Product.asp?vlnk=5768

Continuous Household Survey, Northern Ireland Statistics and Research Agency, available at:

http://www.csu.nisra.gov.uk/survey.asp134.htm

Duncan S and Phillips M, New families for partners, but traditional families for parents? in British Social Attitudes: the 24th Report

Focus on Families, Office for National Statistics, available at: http://www.statistics.gov.uk/focuson/families

Focus on People \& Migration, Office for National Statistics, available at: http://www.statistics.gov.uk/focuson/Migration

General Household Survey, Office for National Statistics, available at: http://www.statistics.gov.uk/ghs

Health Statistics Quarterly, Office for National Statistics, available at: http://www.statistics.gov.uk/statbase/Product.asp?vlnk=6725

HFEA Guide to infertility, Human Fertilisation and Embryology Authority, available at:

http://www.hfea.gov.uk/en/406.html

Marriages Abroad, Government Actuary's Department, available at: http://www.gad.gov.uk/Demography_Data/Marital_status_ projections/2003/marriages_abroad.asp

Population Trends, Office for National Statistics, available at: http://www.statistics.gov.uk/statbase/Product.asp?vlnk=6303

Rise in ageing population and people living alone drives household growth, Communities and Local Government, available at:

http://www.communities.gov.uk/news/corporate/riseageing

Summary statistics on children in care and children adopted from care, British Association for Adoption \& Fostering, available at:

http://www.baaf.org.uk/info/stats/index.shtml

Other useful websites

National Statistics

www.statistics.gov.uk

British Association for Adoption \& Fostering

www.baaf.org.uk

Communities and Local Government

www.communities.gov.uk

Department of Health

www.dh.gov.uk

Eurostat

www.europa.eu.int/comm/eurostat

General Register Office for Scotland

www.gro-scotland.gov.uk

Government Actuary's Department

www.gad.gov.uk

Human Fertilisation and Embryology Authority

www.hfea.gov.uk

Northern Ireland Statistics and Research Agency

www.nisra.gov.uk

Scottish Government

www.scotland.gov.uk

Welsh Assembly Government

www.wales.gov.uk

\section{Chapter 3: Education and training}

References and further reading

British Social Attitudes, Hard copy, National Centre for Social Research, available at:

http://www.natcen.ac.uk/natcen/pages/op_socialattitudes.htm\#bsa
National Employer Skills Survey 2007, Learning and Skills Council, available at: http://readingroom.Isc.gov.uk//sc/National/nat-nessurvey2007 mainreport-may08.pdf

Research Report: Childcare and Early Years Survey 2007 Parents' Use Views and Experiences, National Centre for Social Research for the Department for Children, Schools and Families, available at: http://www.dcsf.gov.uk/research/data/uploadfiles/DCSF-RR025(1).pdf

Research Report: Parental Involvement in Children's Education 2007, BMRB Social Research for the Department of Children, Schools and Families, available at:

http://www.dcsf.gov.uk/research/data/uploadfiles/DCSF-RR034.pdf

Research Report: Skills in Scotland 2006, Futureskills Scotland for the Scottish Government, available at: http://www.scotland.gov.uk/Resource/Doc/919/0065315.pdf

Statistical Volume: Education and Training Statistics for the United Kingdom 2008, (Internet only), Department for Children, Schools and Families, available at:

http://www.dcsf.gov.uk/rsgateway/DB/VOL/v000823/index.shtml

Workforce Training in England 2006, IFF Research Ltd for the Department for Education and Skills, available at:

http://www.dfes.gov.uk/research/data/uploadfiles/RR848.pdf

Youth Cohort Study \& Longitudinal Study of Young People in England: The Activities and Experiences of 16 year olds: England 2007, Department for Children, Schools and Families, available at:

http://www.dcsf.gov.uk/rsgateway/DB/SBU/b000795/YCS_LSYPE_ Bulletin_final.pdf

Other useful websites

National Statistics

www.statistics.gov.uk

Department for Children, Schools and Families

Homepage/Trends/Research and Statistics gateway

www.dcsf.gov.uk

www.dcsf.gov.uk/trends

www.dcsf.gov.uk/rsgateway

Department for Innovation, Universities and Skills

www.dius.gov.uk

Higher Education Statistics Agency

www.hesa.ac.uk

Learning and Skills Council

www.Isc.gov.uk

National Centre for Social Research

www.natcen.ac.uk

National Foundation for Educational Research

www.nfer.ac.uk

Northern Ireland Department for Employment and Learning

www.delni.gov.uk

Northern Ireland Department of Education

www.deni.gov.uk

Organisation for Economic Co-operation and Development www.oecd.org

Office for Standards in Education

www.ofsted.gov.uk

Scottish Government

www.scotland.gov.uk

Welsh Assembly Government

www.wales.gov.uk

\section{Chapter 4: Labour market}

\section{References and further reading}

Employment of foreign workers in the United Kingdom: 1997 to 2008

Office for National Statistics, available at: 
http://www.statistics.gov.uk/elmr/07_08/downloads/ELMR_Jul08_ Clancy.pdf

Labour disputes in 2007, Office for National Statistics, available at: http://www.statistics.gov.uk/elmr/06_08/downloads/ELMR_Jun08 Hale.pdf

Labour Market Guide, Office for National Statistics, available at: http://www.statistics.gov.uk/about/data/guides/LabourMarket/

Local area labour markets: Statistical indicators July 2008, Office for National Statistics, available at:

http://www.statistics.gov.uk/downloads/theme_labour/LALM statistical_indicators_Jul08.pdf

Public sector employment, Office for National Statistics, available at: http://www.statistics.gov.uk/pdfdir/pse0908.pdf

The third work-life balance employee survey: Main findings, Department of Business, Enterprise and Regulatory Reform, available at:

http://www.berr.gov.uk/files/file42645.pdf

Trade union membership 2007, Department of Business, Enterprise and Regulatory Reform, available at:

http://stats.berr.gov.uk/UKSA/tu/tum2008.pdf

Work and worklessness among households, Office for National Statistics, available at:

http://www.statistics.gov.uk/pdfdir/work0808.pdf

Other useful websites

National Statistics

Www.statistics.gov.uk

Department for Business, Enterprise and Regulatory Reform www.berr.gov.uk

Department for Enterprise, Trade and Investment

Northern Ireland

www.detini.gov.uk

Department for Work and Pensions

www.dwp.gov.uk

Eurostat

www.europa.eu.int/comm/eurostat

Jobcentre Plus

www.jobcentreplus.gov.uk

Learning and Skills Council

www.Isc.gov.uk

National Centre for Social Research

www.natcen.ac.uk

Scottish Government

www.scotland.gov.uk

Welsh Assembly Government

www.wales.gov.uk

\section{Chapter 5: Income and wealth}

References and further reading

Annual Survey of Hours and Earnings, Internet only publication, ONS,

available at:

www.statistics.gov.uk/StatBase/Product.asp?vlnk=13101

Brewer M, Goodman A, Myck M, Shaw J and Shephard A (2004)

Poverty and Inequality in Britain: 2004, Commentary no. 96, Institute for Fiscal Studies

Changing Households: The British Household Panel Survey, Institute for Social and Economic Research

Clark T and Leicester A (2004) Inequality and two decades of British tax and benefit reforms Fiscal Studies, vol. 25, pp 129-58

Economic and Labour Market Trends, ONS, Palgrave Macmillan, available at: www.statistics.gov.uk/StatBase/Product.asp?vlnk=308

Eurostat National Accounts ESA, Eurostat
Family Resources Survey, Department for Work and Pensions

Fiscal Studies, Institute for Fiscal Studies

Households Below Average Income, 1994/95-2005/06 (revised), Department for Work and Pensions

Income and Wealth. The Latest Evidence, Joseph Rowntree Foundation Opportunity for All Annual Report, Department for Work and Pensions Pension Trends, ONS, Palgrave Macmillan, available at: www.statistics.gov.uk/StatBase/Product.asp?vlnk=14173

The Pensioners' Incomes Series, Department for Work and Pensions, available at:

www.dwp.gov.uk/asd/pensioners_income.asp

United Kingdom National Accounts (The Blue Book), ONS, Palgrave Macmillan, available at:

www.statistics.gov.uk/StatBase/Product.asp?vlnk=1143

\section{Other useful websites}

National Statistics

www.statistics.gov.uk

Centre for Economic Performance

http://cep.Ise.ac.uk/

Department for Children, Schools and Families

www.dcsf.gov.uk

Department for Work and Pensions

www.dwp.gov.uk

Eurostat

www.europa.eu.int/comm/eurostat

HM Revenue and Customs

www.hmrc.gov.uk

HM Treasury

www.hm-treasury.gov.uk

Institute for Fiscal Studies

www.ifs.org.uk

Institute for Social and Economic Research

www.iser.essex.ac.uk

National Centre for Social Research

www.natcen.ac.uk

National Savings and Investments

www.nsandi.com

\section{Chapter 6: Expenditure}

References and further reading

Consumer Trends, Internet only publication, ONS, available at: www.statistics.gov.uk/consumertrends

Family Spending, ONS, Palgrave Macmillan, available at: www.statistics.gov.uk/StatBase/Product.asp?vlnk=361

Financial Risk Outlook Report, 2008, Financial Services Authority http://www.fsa.gov.uk/pubs/plan/financial_risk_outlook_2008.pdf

Focus on Consumer Price Indices, ONS, Palgrave Macmillan, available at: www.statistics.gov.uk/StatBase/Product.asp?vlnk=867

Households Below Average Income, 1994/95-2005/06, Department for Work and Pensions

http://www.dwp.gov.uk/mediacentre/pressreleases/2007/apr/

drc027-230407.asp

Other useful websites

APACS - The UK Payments Association

www.apacs.org.uk

Bank of England

www.bankofengland.co.uk 
Department for Work and Pensions

www.dwp.gov.uk/

Financial Services Authority

www.fsa.gov.uk/

Insolvency Service

www.insolvency.gov.uk

\section{Chapter 7: Health}

\section{References and further reading}

Alcohol-related deaths 1991-2007, ONS, available at:

www.statistics.gov.uk/CCl/nugget.asp?ID=1091\&Pos=1\&ColRank=28 \&Rank=1000

Alcohol-related deaths by occupation, England and Wales, 2001-2005, available at: Health Statistics Quarterly, No.35:

www.statistics.gov.uk/cci/article.asp?ID $=1851 \& P O S=2 \&$ ColRank $=1 \&$ Rank=1

Annual Report of the Registrar General for Northern Ireland,

Northern Ireland Statistics and Research Agency, available at:

http://www.nisra.gov.uk/archive/demography/publications/ annual_reports/2007/RG2007.pdf

Annual Report of the Registrar General for Scotland, General Register Office for Scotland, available at:

www.gro-scotland.gov.uk/statistics/publications-and-data/ annual-report-publications/rgs-annual-review-2007/index.html

At Least Five a Week - Evidence on the Impact of Physical Activity and its Relationship to Health, A Report from the Chief Medical Officer,

Department of Health, available at:

www.dh.gov.uk/PublicationsAndStatistics/Publications/

PublicationsPolicyAndGuidance/

PublicationsPolicyAndGuidanceArticle/fs/en?CONTENT_

$\mathrm{ID}=4080994 \& \mathrm{chk}=1 \mathrm{Ft} 10 f$

Choosing Health - Making Healthy Choices Easier, Cm6374, TSO, available at: www.dh.gov.uk/PublicationsAndStatistics/Publications/

PublicationsPolicyAndGuidance/

PublicationsPolicyAndGuidanceArticle/fs/en?CONTENT_

ID $=4094550 \&$ chk $=$ aN5Cor

Contraception and Sexual Health, 2007/08, ONS, Palgrave Macmillan, available at:

www.statistics.gov.uk/downloads/theme_health/contra2007-8.pdf

Family Food - Report on the Expenditure and Food Survey, Department for Environment, Food and Rural Affairs, available at:

https://statistics.defra.gov.uk/esg/publications/efs/default.asp

Focus on Health 2006, ONS, available at:

www.statistics.gov.uk/focuson/health

General Household Survey (Longitudinal) 2006, Internet only publication, ONS, available at:

www.statistics.gov.uk/ghs

Geographic variations in deaths related to drug misuse in England and Wales between 1993 and 2006, available in Health Statistics Quarterly, 2008, Vol. 39, page 14

http://nswebcopy/statbase/Product.asp?vlnk=6725

Health Expectancies in the United Kingdom 2003, Health Statistics Quarterly, no 33, pp 69-70, ONS, available at: www.statistics.gov.uk/downloads/theme_health/hsq33web.pdf

Health in Scotland. The Annual Report of the Chief Medical Officer on the State of Scotland's Health, Scottish Executive, available at: www.scotland.gov.uk/Publications/2007/11/15135302/0

Health Statistics Quarterly, available on the ONS website: http://nswebcopy/statbase/Product.asp?vlnk=6725

Health Statistics Wales, Welsh Assembly Government, available at: www.wales.gov.uk/topics/statistics/theme/health/?lang=en

Health Survey for England, Information Centre for health and social care, available at:
wWw.ic.nhs.uk/statistics-and-data-collections/health-and-lifestylesrelated-surveys/health-survey-for-England

HIV in the UK, 2008 report; Health Protection Agency, available at: http://www.hpa.org.uk/webw/

HPAweb\&Page\&HPAwebAutoListName/Page/1203439654589? $p=120$ 3439654589

Inequalities in young people's health: HBSC international report from the 2005/2006 survey, World Health Organisation Regional Office for Europe, available at:

www.euro.who.int/datapublications/Publications/

Catalogue/20080616_1

Mortality Statistics for England and Wales (Series DH1, 2, 3, 4),

Internet only publications ONS, available at:

www.statistics.gov.uk/statbase/Product.asp?vlnk $=620$

wWw.statistics.gov.uk/statbase/Product.asp?vlnk $=618$

wWw.statistics.gov.uk/statbase/Product.asp?vlnk=6305

www.statistics.gov.uk/statbase/Product.asp?vlnk $=621$

ONS drug-related deaths database: first results for England and Wales, 1993-1997, available in Health Statistics Quarterly, 2000, Vol. 5, page 35 http://nswebcopy/statbase/Product.asp?vlnk=6725

On the State of the Public Health - The Annual Report of the Chief Medical Officer of the Department of Health, Department of Health, available at:

www.dh.gov.uk/en/Publicationsandstatistics/Publications/ AnnualReports/DH_076817

Opinions (Omnibus) Survey, Office for National Statistics, available at: www.ons.gov.uk/about/who-we-are/our-services/omnibus-survey/ index.htm

Population Trends, ONS, Palgrave Macmillan, available at: www.statistics.gov.uk/statbase/Product.asp?vlnk=6303

Quinn M, Wood H, Cooper N and Rowan S (2005) Cancer Atlas of the United Kingdom and Ireland 1991-2000, ONS, Palgrave Macmillan, available at:

www.statistics.gov.uk/statbase/Product.asp?vlnk=14059

Registrations of cancer diagnosed in 2006, England, Office for National

Statistics, available at:

www.statistics.gov.uk/downloads/theme_health/MB1-37/

MB1_37_2006.pdf

Report of the Chief Medical Officer, Department of Health, Social Services and Public Safety, Northern Ireland, available at:

www.dhsspsni.gov.uk/index/phealth/cmoannualreport.htm

Results of the ICD-10 bridge coding study, England and Wales, 1999,

Health Statistics Quarterly, no 14, pp 75-83, available at:

www.statistics.gov.uk/downloads/theme_health/HSQ14_v4.pdf

Sexually transmitted infections and Men who have sex with Men in the UK 2008 report; Health Protection Agency, available at:

http://www.hpa.org.uk/webw/

HPAweb\&Page\&HPAwebAutoListName/Page/1203439654589? $p=120$ 3439654589

Sexually transmitted Infections and Young People in the UK: 2008 report Health Protection Agency Centre for Infections, available at: http://www.hpa.org.uk/web/HPAweb\&HPAwebStandard/ HPAweb_C/1216022460726

Sexually transmitted infections in black African and black Caribbean communities in the UK: 2008 report. Health Protection Agency,

available at:

http://www.hpa.org.uk/webw/

HPAweb\&Page\&HPAwebAutoListName/Page/1203439654589? $p=120$ 3439654589

Smoking-related Behaviour and Attitudes 2006, Internet only publications ONS, available at:

www.statistics.gov.uk/downloads/theme_health/smoking2006.pdf

Tackling Health Inequalities: Status Report on the Programme for Action,

Department of Health, available at:

www.dh.gov.uk/en/Publicationsandstatistics/Publications/

PublicationsPolicyAndGuidance/DH_062903 
The NHS Cancer Plan 2000, NHS, available at: www.dh.gov.uk/prod_consum_dh/groups/dh_digitalassets/@dh/@ en/documents/digitalasset/dh_4014513.pdf

Trends and geographical variations in alcohol-related death in the UK, 1991-2004, Health Statistics Quarterly, 2007, no 33, pp 9-10, available at: www.statistics.gov.uk/downloads/theme_health/hsq33web.pdf

United Kingdom Health Statistics 2006, ONS, Palgrave Macmillan, available at:

www.statistics.gov.uk/downloads/theme_health/ukhs2/ukhs2_rel1_ superseded.pdf

Welsh Health: Annual Report of the Chief Medical Officer, Welsh Assembly Government, available at:

http://wales.gov.uk/topics/health/ocmo/communications/ annualreport/2007/?lang=en

World Health Statistics, World Health Organisation, available at: www.who.int/whosis/en/

\section{Other useful websites}

Department for Environment, Food and Rural Affairs www.defra.gov.uk

Department of Health

www.dh.gov.uk

Department of Health, Social Services and Public Safety, Northern Ireland www.dhsspsni.gov.uk/stats\&research/index.asp

General Register Office for Scotland

www.gro-scotland.gov.uk

Government Actuary's Department

www.gad.gov.uk

Health Protection Agency

www.hpa.org.uk

Health Behaviour in School-aged Children

www.hbsc.org/

The NHS Information Centre for health and social care www.ic.nhs.uk

Information Services Division Scotland

www.isdscotland.org

Northern Ireland Cancer Registry

www.qub.ac.uk/nic

Northern Ireland Statistics and Research Agency

www.nisra.gov.uk

Scottish Government

www.scotland.gov.uk

Welsh Assembly Government

www.wales.gov.uk

Welsh Cancer Intelligence and Surveillance Unit

www velindre-tr.wales.nhs.uk/wcisu

\section{Chapter 8: Social protection}

References and further reading

Annual Statistical Publication Notices, Scottish Government, available at: http://www.scotland.gov.uk/Topics/Statistics/

Benefit expenditure and caseload information, Department for Work and Pensions, available at:

www.dwp.gov.uk/asd/asd4/expenditure.asp

British Social Attitudes - The 25th Report, National Centre for Social Research, Sage publications, available at:

www.natcen.ac.uk/natcen/pages/nm_pressreleases.htm

The Carers, Employment and Services Report 4, Carers UK, available at: http://www.carersuk.org/Policyandpractice/Research/ CarersEmploymentandServices/1201172496
Children looked after statistics in Scotland, available at: www.scotland.gov.uk/Topics/Statistics/Browse/Children/ PubChildrenLookedAfter

Community Care Statistics 2007: Home Help/Care Services for Adults, England - NHS, available at: http://www.ic.nhs.uk/statistics-and-data-collections/social-care/ adult-social-care-information/community-care-statistics-2007-08:grant-funded-services-for-adults-england

Conolly and Kerr (2008), Families with children in Britain: Findings from the 2006 Families and Children Study (FACS), Department for Work and Pensions, Corporate Document Services, available at:

www.dwp.gov.uk/asd/asd5/report_abstracts/rr_abstracts/rra_486.asp ESSPROS Manual 1996, Eurostat

Family Resources Survey, Department for Work and Pensions, available at: www.dwp.gov.uk/asd/frs

General Household Survey 2007, Internet only publication, ONS

available at: www.statistics.gov.uk/ghs

Health Statistics Wales, Children and young people, Welsh assembly Government, available at: http://new.wales.gov.uk/topics/?lang=en

Hospital Statistics for Northern Ireland, Department of Health, Social Services and Public Safety, Northern Ireland, available at www.dhsspsni.gov.uk/index/stats_research/stats-activity_stats-2.htm Mooney E, Fitzpatrick M, and Hewitt R (2007) Children Order Statistical Bulletin, Department of Health, Social Services and Public Safety, Northern Ireland, available at:

www.dhsspsni.gov.uk/stats-cib-children_order_bulletin

Referrals, assessments and children and young people on child protection registers, England (First Release), Department for children, schools and families, available at: www.dcsf.gov.uk/rsgateway/whatsnew.shtml

Social Services Statistics Wales, Local Government Data Unit, available at: www.dataunitwales.gov.uk

Other useful websites

National Statistics

www.statistics.gov.uk

Carers UK

www.carersuk.org

Charities Aid Foundation

www.cafonline.org

Department for Children, Schools and Families www.dcsf.gov.uk

Department of Health, Social Services and Public Safety, Northern Ireland www.dhsspsni.gov.uk

Department for Social Development, Northern Ireland www.dsdni.gov.uk

Department for Work and Pensions

www.dwp.gov.uk

Department of Health

www.dh.gov.uk

Eurostat

www.europa.eu.int/comm/eurostat

Local Government Data Unit

www.dataunitwales.gov.uk

www.unedddatacymru.gov.uk

National Society for the Prevention of Cruelty to Children www.nspcc.org.uk

The NHS Information Centre for health and social care www.ic.nhs.uk

The Organisation for Economic Co-operation and Development www.oecd.org 
Scottish Government www.scotland.gov.uk

Welsh Assembly Government

www.wales.gov.uk

\section{Chapter 9: Crime and justice}

References and further reading

Circumstances of crime, Neighbourhood Watch membership and perceptions of policing: Supplementary volume 3 to Crime in England and Wales 2006/07, Home Office, available at:

http://www.homeoffice.gov.uk/rds/pdfs08/hosb0608.pdf

Crime in England and Wales 2007/08, Home Office, available at: http://www.homeoffice.gov.uk/rds/pdfs08/hosb0708.pdf

Crime in England and Wales 2006/07, Home Office, available at: http://www.homeoffice.gov.uk/rds/pdfs07/hosb1107.pdf

Criminal Justice System Strategic plan 2008-2011, Office for Criminal Justice Reform (OCJR), available at:

http://www.cjsonline.gov.uk/downloads/application/pdf/1

Strategic_Plan_ALL.pdf

Criminal Statistics England and Wales 2007, available at: http://www.justice.gov.uk/publications/criminalannual.htm

A Guide to anti-social behaviour orders and acceptable behaviour contracts (2007), Home Office, available at:

www.crimereduction.homeoffice.gov.uk/asbos/asbos9.pdf

Home Office Research Findings, Home Office, available at: www.homeoffice.gov.uk/rds/pubsintro1.html

Home Office Statistical Bulletins, Home Office, available at: www.homeoffice.gov.uk/rds/hosbpubs1.html

Homicides, Firearm offences and Intimate Violence 2006/07:

Supplementary Volume 2 to Crime in England and Wales 2006/07,

Home Office, available at:

http://www.homeoffice.gov.uk/rds/pdfs08/hosb0308.pdf

Hough M, Hunter G, Jacobson J, and Cossalter S, Research Report 04,

The impact of the Licensing Act 2003 on levels of crime and disorder:

an evaluation, Institute of Public Policy Research, Kings College London

Northern Ireland Crime Survey Bulletins, Northern Ireland Office,

available at:

http://www.nio.gov.uk/statistics-research/publications.htm

Northern Ireland Judicial Statistics, Northern Ireland Court Service,

available at:

http://www.courtsni.gov.uk/en-GB/Publications/Targets_and_

Performance/

Offender Management Caseload Statistics, Ministry of Justice, available at: http://www.justice.gov.uk/publications/prisonandprobation.htm

Offending, Crime and Justice Survey, 2006, Home Office, available at: http://www.homeoffice.gov.uk/rds/pdfs08/hosb0908.pdf

Police Service of Northern Ireland Annual Statistics, 2007/08, Police Service of Northern Ireland, available at:

http://www.psni.police.uk/index/updates/updates_statistics/ update_crime_statistics.htm

Population in Custody: Monthly tables, Ministry of Justice, available at: http://www.justice.gov.uk/publications/populationincustody.htm

Recorded Crime in Scotland 2007/08, Scottish Government, available at: http://www.scotland.gov.uk/Publications/2008/09/29155946/0

Scotland crime and justice statistics, Scottish Government, available at: http://www.scotland.gov.uk/Topics/Statistics/Browse/Crime-Justice

Scottish Crime and Victimisation Survey 2006, Scottish Government, available at:

http://www.scotland.gov.uk/Publications/2007/10/12094216/13

Sentencing Statistics, 2007 England and Wales (annual)

http://www.justice.gov.uk/publications/prisonandprobation.htm
Other useful websites

Court Service

www.hmcourts-service.gov.uk

Criminal Justice System

www.cjsonline.org

Crown Prosecution Service

www.cps.gov.uk

Department of Constitutional Affairs

www.dca.gov.uk

Home Office

www.homeoffice.gov.uk

Judiciary of England and Wales

www.judiciary.gov.uk

Ministry of Justice

www.justice.gov.uk

Northern Ireland Court Service

www.courtsni.gov.uk

Northern Ireland Office

www.nio.gov.uk

Northern Ireland Prison Service www.niprisonservice.gov.uk

Police Service of Northern Ireland www.psni.police.uk

Prison Service for England and Wales www.hmprisonservice.gov.uk

Scottish Government

www.scotland.gov.uk

Scottish Prison Service

www.sps.gov.uk

Welsh Assembly Government

www.wales.gov.uk

\section{Chapter 10: Housing}

References and further reading

Continuous Household Survey, Northern Ireland Statistics and Research Agency, available at:

http://www.csu.nisra.gov.uk/survey.asp29.htm

e-digest Statistics about: Land Use and Land Cover - Urbanisation in England, Department for Environment, Food and Rural Affairs (DEFRA), available at:

www.defra.gov.uk/environment/statistics/land/lduse.htm

English House Condition Survey 2006, Communities and Local Government, TSO, available at:

http://www.communities.gov.uk/publications/corporate/statistics/ ehcs2006annualreport

General Household Survey (Longitudinal) 2007, Internet only publication ONS, available at:

www.statistics.gov.uk/ghs

Housing in England: Survey of English Housing, Communities and Loca Government, TSO, available at:

http://www.communities.gov.uk/publications/corporate/statistics/ housingengland2006-07

Housing Statistics 2008, Communities and Local Government, TSO available at:

http://www.communities.gov.uk/publications/corporate/statistics/ housingstatistics 2008

Lifetime Homes, Lifetime Neighbourhoods: A National Strategy for Housing in an Ageing Society, Communities and Local Government, available at: http://www.communities.gov.uk/publications/housing/

lifetimehomesneighbourhoods 
New Projections of households for England and the Regions to 2029 (2007), Communities and Local Government, TSO, available at: www.communities.gov.uk/news/corporate/new-projectionhouseholds

Scottish House Condition Survey, Scottish Government, available at: www.scotland.gov.uk/Topics/Statistics/SHCS

Statistical Bulletins on Housing, Scottish Executive, available at: www.scotland.gov.uk/Topics/Housing

Other useful websites

National Statistics

www.statistics.gov.uk

Communities and Local Government

www.communities.gov.uk

Council of Mortgage Lenders

www.cml.org.uk

Department for Social Development, Northern Ireland

www.dsdni.gov.uk

HM Revenue and Customs

www.hmrc.gov.uk

Land Registry

www.landregistry.gov.uk

Neighbourhood Renewal Unit

www.neighbourhood.gov.uk

Northern Ireland Statistics and Research Agency

www.nisra.gov.uk

Scottish Government

www.scotland.gov.uk

Welsh Assembly Government

www.wales.gov.uk

\section{Chapter 11: Environment}

References and further reading

Agriculture in the United Kingdom, Department for Environment, Food and Rural Affairs, TSO, available at:

http://statistics.defra.gov.uk/esg/publications/auk/default.asp

Air Quality Strategy for England, Scotland, Wales and Northern Ireland Department for Environment, Food and Rural Affairs, TSO, available at: www.defra.gov.uk/environment/airquality/index.htm

Attitudes of European citizens towards the environment, European Commission, available at:

http://ec.europa.eu/public_opinion/archives/ebs/ebs_295_en.pdf

Bathing water quality, 2007 bathing season, Eurostat, available at: http://ec.europa.eu/environment/water/water-bathing/summary_ report_2008.html

Digest of United Kingdom Energy Statistics 2008, Department for Business, Enterprise and Regulatory Reform, TSO, available at:

http://www.berr.gov.uk/whatwedo/energy/statistics/publications/ dukes/page45537.htm

e-Digest of Environmental Statistics, Department for Environment,

Food and Rural Affairs, available at:

www.defra.gov.uk/environment/statistics/index.htm

Energy consumption in the UK, Department for Business, Enterprise and Regulatory Reform, available at:

www.berr.gov.uk/whatwedo/energy/statistics/publications/ecuk/ page17658.html

Energy Trends, Department for Business, Enterprise and Regulatory Reform, available at:

www.berr.gov.uk/energy/statistics/publications/trends/index.html

Ensuring the UK's Food Security in a Changing World, Department for

Environment, Food and Rural Affairs, available at:
http://www.defra.gov.uk/foodrin/policy/pdf/Ensuring-UK-FoodSecurity-in-a-changing-world-170708.pdf

Europe in figures - Eurostat yearbook 2008, Eurostat, available at: http://epp.eurostat.ec.europa.eu/pls/portal/url/page/PGP MISCELLANEOUS/PGE_DOC_DETAIL?p_product_code=KS-CD-07-001

Hydrological Summaries for the United Kingdom, Centre for Ecology and Hydrology Wallingford and British Geological Survey, available at: www.ceh.ac.uk/data/nrfa/water_watch.html

Municipal Waste Management, Welsh Assembly Government, available at: http://new.wales.gov.uk/topics/environmentcountryside/epq/ waste_recycling/municipalwastemanagement/;jsessionid=9WkSJvKD 2YyvlldLQdXLQTJB2jgzxMwTtV8Cr3Tw8Pf284S60rh3!1130397166 ?lang=en

Municipal Waste Statistics, Department for Environment, Food and Rural Affairs, available at:

www.defra.gov.uk/environment/statistics/wastats/

Organic Statistics UK, Department for Environment, Food and Rural Affairs, available at:

http://statistics.defra.gov.uk/esg/statnot/orguk.pdf

Quarterly Energy Prices, Department for Business, Enterprise and Regulatory Reform, available at:

http://www.berr.gov.uk/whatwedo/energy/statistics/publications/ prices/index.html

Pollution incidents, Environment Agency, available at: http://www.environment-agency.gov.uk/research/library/ data/34363.aspx

Survey of Public Attitudes to Quality of Life and to the Environment - 2007, Department for Environment, Food and Rural Affairs, available at: www.defra.gov.uk/environment/statistics/pubatt/index.htm

Sustainable Development Indicators in your Pocket 2008, Department for Environment, Food and Rural Affairs, available at:

http://www.defra.gov.uk/sustainable/government/progress/ data-resources/sdiyp.htm

The Environment in your Pocket 2008, Department for Environment, Food and Rural Affairs, available at: www.defra.gov.uk/environment/statistics/eiyp/index.htm

The food we waste, Waste \& Resources Action Programme, available at: http://www.wrap.org.uk/applications/publications/publication_ details.rm?id=698\&publication $=5635$ \&programme $=$ wrap

Wild bird populations 2007, Department for Environment, Food and Rural Affairs, available at:

http://www.defra.gov.uk/Environment/statistics/wildlife/download/ pdf/NSBirds20081031.pdf

\section{Other useful websites}

Centre for Ecology and Hydrology

www.ceh-nerc.ac.uk

Centre for Environment, Fisheries \& Aquaculture Science www.cefas.co.uk/

Department of Energy and Climate Change

www.decc.gov.uk

Department for Environment, Food and Rural Affairs www.defra.gov.uk

Department of the Environment Northern Ireland www.doeni.gov.uk

Environment Agency

www.environment-agency.gov.uk

Eurostat

www.europa.eu.int/comm/eurostat

Northern Ireland Statistics and Research Agency

www.nisra.gov.uk

Populus

www.populuslimited.com/ 
Scottish Environment Protection Agency

www.sepa.org.uk

Scottish Government

www.scotland.gov.uk

Waste \& Resources Action Programme

www.wrap.org.uk/

Welsh Assembly Government

www.wales.gov.uk

\section{Chapter 12: Transport}

References and further reading

British Social Attitudes - The 25th Report, National Centre for Social Research, Sage publications, available at:

www.natcen.ac.uk/natcen/pages/nm_pressreleases.htm

Driving Standards Agency Annual Report and Accounts 2007/08,

Driving Standards Agency, TSO, available at:

http://www.official-documents.gov.uk/document/hc0708/

hc07/0738/0738.asp

European Union Energy and Transport in Figures, 2007, European

Commission, available at:

http://ec.europa.eu/dgs/energy_transport/figures/pocketbook/

2007_en.htm

Focus on Personal Travel: 2005 edition, Department for Transport, TSO, available at:

www.dft.gov.uk/pgr/statistics/datatablespublications/personal/ focuspt/2005/focusonpersonaltravel2005edi5238

General Household Survey (Longitudinal) 2007, Internet only publication, ONS, available at:

www.statistics.gov.uk/ghs

Injury Road Traffic Collision Statistics Annual Report 2007/08, Police Service of Northern Ireland, available at:

http://www.psni.police.uk/injury_road_traffic_stats_financial_ year_2007-08.pdf

National Passenger Survey Spring 2008, Passenger Focus, available at: www.passengerfocus.org.uk/your-experiences/content. asp?dsid=496

National Rail Trends 2006-07 Yearbook, Office of Rail Regulator, available at:

www.rail-reg.gov.uk/server/show/ConWebDoc.8802

National Trave/ Survey Bulletins, Department for Transport, available at: http://www.dft.gov.uk/pgr/statistics/recentpubs/recentpublications

A New Deal for Transport: Better for Everyone (2005), Department for Transport, TSO, available at:

www.dft.gov.uk/about/strategy/whitepapers/previous/ anewdealfortransportbetterfo5695

Northern Ireland Transport Statistics Annual 2007-2008, Department for Regional Development Northern Ireland, available at: http://www.drdni.gov.uk/transport_statistics_annual_2007-08.pdf

Office of Rail Regulation Annual report 2007-08, Office of Rail Regulation, available at:

http://www.rail-reg.gov.uk/server/show/nav.1240

Road Accidents Scotland 2007, Scottish Government, available at: http://www.scotland.gov.uk/Topics/Statistics/Browse/TransportTravel/PubRoadAcc

Road Casualties Great Britain 2007 - Annual Report, Department for Transport, TSO, available at:

http://www.dft.gov.uk/pgr/statistics/datatablespublications/ accidents/casualtiesgbar/roadcasualtiesgreatbritain20071

Road Casualties: Wales 2006, Welsh Assembly Government, available at: http://new.wales.gov.uk/topics/statistics/publications/ rcw2006/?lang=en

Scottish Government Transport publications and bulleting pages, available at:
http://www.scotland.gov.uk/Topics/Statistics/Browse/TransportTravel/Publications

Scottish Household Survey 2007, available at:

http://www.scotland.gov.uk/Topics/Statistics/16002/

PublicationAnnual

Scottish Transport Statistics: No 26, 2007 Edition, Scottish Executive,

available at:

http://www.scotland.gov.uk/Publications/2007/12/14120610/9

Securing the Future - UK Government sustainable development strategy (2005), Department for Environment, Food and Rural Affairs, TSO,

available at:

http://www.defra.gov.uk/sustainable/government/progress/index.htm

Traffic Speeds and Congestion 2006, Department for Transport,

available at:

http://www.dft.gov.uk/pgr/statistics/datatablespublications/ roadstraffic/speedscongestion/roadstatstsc/roadstats07tsc

Transport Statistics Bulletins and Reports, Department for Transport, available at:

http://www.dft.gov.uk/pgr/statistics/recentpubs/recentpublications

Transport Statistics for Great Britain 2008, Department for Transport, TSO, available at:

http://www.dft.gov.uk/pgr/statistics/datatablespublications/ tsgb/2008edition/

Transport Trends 2008, Department for Transport, TSO, available at: http://www.dft.gov.uk/pgr/statistics/datatablespublications/trends/ current/

Travel Trends, ONS, Palgrave Macmillan, available at: www.statistics.gov.uk/statbase/Product.asp?vlnk=1391

Vehicle Licensing Statistics 2007, Department for Transport, available at: http://www.dft.gov.uk/pgr/statistics/datatablespublications/ vehicles/licensing/vehiclelicensingstatistics2007

Vehicle Speeds in Great Britain 2007, Department for Transport, available at:

http://www.dft.gov.uk/pgr/statistics/datatablespublications/ roadstraffic/speedscongestion/roadstatstsc/roadstats 07 tsc

Welsh Transport Statistics, Welsh Assembly Government, available at: http://new.wales.gov.uk/topics/statistics/theme/transport/?lang=en

Other useful websites

National Statistics

www.statistics.gov.uk

Civil Aviation Authority, Economic Regulation Group

www.caa.co.uk/homepage.aspx

Department of Energy and Climate Change

www.decc.gov.uk

Department of the Environment Northern Ireland www.doeni.gov.uk

Department for Regional Development Northern Ireland www.drdni.gov.uk

Department for Transport

www.dft.gov.uk

European Commission Directorate-General Energy and Transport www.ec.europa.eu/dgs/energy_transport/index_en.html

National Centre for Social Research

www.natcen.ac.uk

Office of Rail Regulation

www.rail-reg.gov.uk

Passenger Focus

www.passengerfocus.org.uk

Police Service of Northern Ireland

www.psni.police.uk

Scottish Government

www.scotland.gov.uk 
Welsh Assembly Government www.wales.gov.uk

\section{Chapter 13: Lifestyles and social participation}

\section{References and further reading}

Citizenship Survey: April-June 2008, England, Communities and Local Government, available at:

http://www.communities.gov.uk/publications/corporate/statistics/ citizenshipsurveyq12008-09

Helping Out, a national survey of volunteering and charitable giving, 2006/07, Cabinet Office, available at:

www.cabinetoffice.gov.uk/third_sector/Research_and_statistics/ third_sector_research/helping_out.aspx

Internet Access 2008, First Release, Office for National Statistics, available at:

http://www.statistics.gov.uk/pdfdir/iahi0808.pdf

Media Literacy Audit: Report on UK children's media literacy, Ofcom, available at:

http://www.ofcom.org.uk/advice/media_literacy/medlitpub/ medlitpubrss/ml_childrens08/ml_childrens08.pdf

Media Literacy Audit: Report on UK adults' media literacy, Ofcom, available at: http://www.ofcom.org.uk/advice/media_literacy/medlitpub/ medlitpubrss/ml_adult08/ml_adults08.pdf

Quick S, 2007/08 School Sport Survey, Department for Children, Schools and Families, available at:

http://www.dcsf.gov.uk/research/programmeofresearch/ projectinformation.cfm?projectid $=15567$ \& resultspage $=1$

Sainsbury M and Clarkson R, Reading at Ages Nine and Eleven, Full Report (2008), available at:

http://www.nfer.ac.uk/publications/pdfs/downloadable/RAQ.pdf

Social Networking, a quantitative and qualitative report into attitudes, behaviours and use, Ofcom, available at:

http://www.ofcom.org.uk/advice/media_literacy/medlitpub/ medlitpubrss/socialnetworking/report.pdf

Taking Part: The National Survey of Culture, Leisure and Sport, Department of Culture, Media and Sport, available at: http://www.culture.gov.uk/reference_library/research_and statistics/4828.aspx

Travel Trends: Data tables on the 2007 International Passenger Survey, available at:

http://www.statistics.gov.uk/statbase/Product.asp?vlnk=1391
UK Giving 2008, Charities Aid Foundation and National Council of Voluntary Organisations, available at:

www.cafonline.org/ukgiving

Wardle H, Sproston K, Orford J, Erens B, Griffiths M, Constantine R, and Pigott S, British Gambling Prevalence Survey 2007, available at: http://www.gamblingcommission.gov.uk/Client/detail. asp?Contentld=311

Other useful websites

Cabinet Office

www.cabinetoffice.gov.uk

Charities Aid Foundation

www.cafonline.org

Communities and Local Government

www.communities.gov.uk

Department for Children, Schools and Families www.dcsf.gov.uk

Department for Culture, Media and Sport www.culture.gov.uk

Gambling Commission www.gamblingcommission.gov.uk

National Centre for Social Research www.natcen.ac.uk

National Foundation for Educational Research www.nfer.ac.uk

National Lottery Commission www.natlotcomm.gov.uk

National Readership Survey

www.nrs.co.uk/

Ofcom

www.ofcom.org.uk/research

Populus

www.populus.co.uk

Public Lending Right

www.plr.uk.com

VisitBritain

www.visitbritain.co.uk/ 